\title{
Cartographic analysis of some old Transylvanian geological maps from the second half of the nineteenth century
}

\author{
Enikő Korodi ${ }^{1} \cdot$ Zsombor Bartos-Elekes $^{1}$ • \\ Ioan Rus ${ }^{1} \cdot$ Ionel Haidu ${ }^{2}$
}

Received: 12 March 2015/Accepted: 1 July 2015/Published online: 17 July 2015

(C) Akadémiai Kiadó 2015

\begin{abstract}
Old geological maps are extremely important sources of information about the state of geological knowledge of a specific period. Using GIS techniques, the old geological data and concepts can be compared and analyzed together with modern ones. Thus, the aim of this work is to present some old Transylvanian geological maps from the second half of the nineteenth century, with special respect to their legend and topographic basis, as well as to discuss the georeferencing methods and results in order to incorporate them into a unified GIS database. The geological maps of this study are the followings: the geognostic map of the Habsburg Empire by Haidinger (Geognostische Uibersichts-Karte der Oesterreichischen Monarchie 1845); the geological map of Transylvania by Hauer et al. (General-Karte des Grossfürstenthums Siebenbürgen und der im Jahre 1861 mit dem Königreiche Ungarn vereinigten Theile 1863); the geological map of the Habsburg Empire by Hauer (Geologische Übersichts-Karte der Österreichisch-Ungarischen Monarchie nach den Aufnahmen der k. k. geologischen Reichsanstalt 1867-1871); the geological map of the Seklerland by Herbich (A Székelyföld földtani térképe 1878a). These maps were compiled using as topographic basis the map sheets of the 1st and 2nd Military Survey of the Habsburg Empire (later Austro-Hungarian Monarchy).
\end{abstract}

Keywords Transylvania · Historical cartography · Old geological maps · Map projection · Georeference

Enikő Korodi

korodi.eniko@yahoo.com

Zsombor Bartos-Elekes

bezsombor@geografie.ubbcluj.ro

Ioan Rus

nelurus@geografie.ubbcluj.ro

Ionel Haidu

ionel.haidu@univ-lorraine.fr

1 Faculty of Geography, Babeş-Bolyai University, 400006 Cluj-Napoca, Romania

2 Laboratoire LOTTER - EA 7304, Université de Lorraine, Ile du Saulcy, 57045 Metz, France 


\section{Introduction}

Geological maps are special-purpose thematic maps: they show, on topographic base maps information regarding the petrographic composition, structure and stratigraphic succession (succession in time) of the geological features. The distribution of the geological features is represented by colors, lines and special symbols unique to geologic maps. Colors and symbols also indicate the age of the geological formations (Brezsnyánszky 2001, pp. 4-8, 2007; Galambos 2004, 2009a).

Geological maps can be analyzed on the one hand from the perspective of the symbols (legend), and on the other hand from the viewpoint of the topographic base maps used. The utilized symbol system hadn't always been unified and conventional; before the 2nd International Geological Congress, Bologna, 1881 (standardization of the usage of the colors and geological nomenclature) it had depended on the options of the author of the map. The knowledge of the map projection, geodetic datum and prime meridian used for the topographic base maps is also extremely important because it is the key for the georeferencing, and thus for the GIS applications (Galambos 2009b, 2010a). Integration of the historical geological maps into a GIS database makes possible the analysis and comparison of old geological data and knowledge with modern ones.

In the beginning, geological maps showing Transylvania (as a part of the Habsburg Monarchy) were compiled by foreign travelers (e.g. Robert Townson, Stanisłav Staszic, François Sulpice Beudant, Ami Boué). The systematic geological mapping started in the mid-nineteenth century (in the Habsburg Empire, similarly to other European countries), favored by the foundation of the Imperial Geological Institute in Vienna (1849), and later by the foundation of the Royal Hungarian Geological Institute in Budapest (1869) (Barczikayné Szeiler et al. 2009; Galambos and Unger 2009; Maigut 2010, p. 12).

The aim of this paper is to present some old geological maps showing Transylvania from the second half of the nineteenth century, with special respect to their legend and topographic basis, as well as the georeferencing methods and results in order to incorporate them into a GIS database. For the time being, we have georeferenced the maps presenting the whole territory of the Habsburg Empire (the geognostic map by Haidinger 1845, at a scale of 1:864,000; the geological map by Hauer 1867-1871, at a scale of 1:576,000—only the sheets showing Transylvania), as well as the map by Hauer et al. (1863) showing Transylvania and the map by Herbich (1878a) about Seklerland (the latter two on a scale of $1: 288,000)$.

\section{Overview of the old geological maps showing Transylvania from the second half of the nineteenth century}

\subsection{The geognostic map of the Habsburg Empire by Haidinger, sheet VI (Haidinger 1845)}

Based on the geological data coming from the first half of the nineteenth century, Wilhelm Haidinger compiled the geognostic map of the Habsburg Empire (1845) at the scale of 1:864,000 (Fig. 1), comprising 9 sheets.

Concerning its topographic basis, there are two different assumptions: Brezsnyánszky (1996) and Brezsnyánszky and Síkhegyi (2007) described it as a derivation of the map sheets based on the Second Military Survey (1806-1869). They corrected themselves later, 


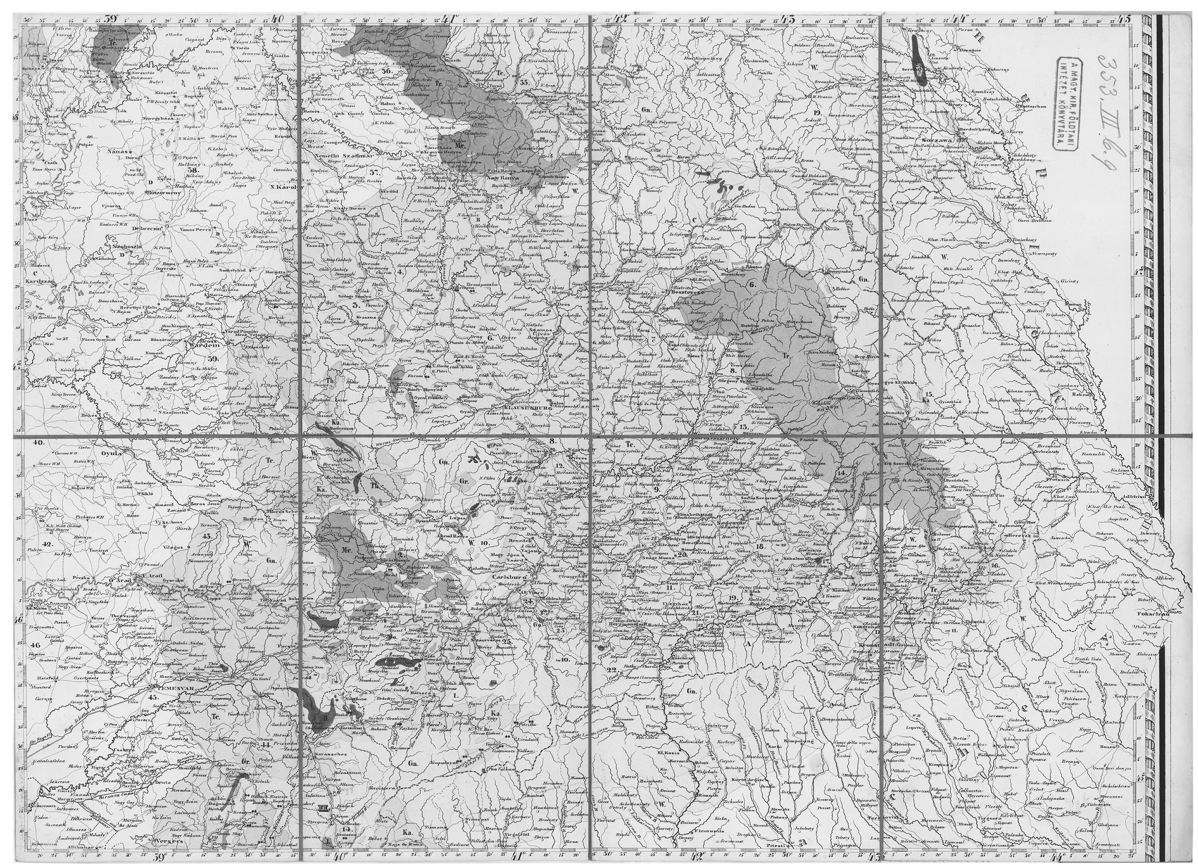

Fig. 1 Sheet VIth (showing Transylvania) of the geognostic map by Haidinger (Geognostische UibersichtsKarte der Oesterreichischen Monarchie), 1:864,000 (Haidinger 1845) Collection of the Library of the Geological and Geophysical Institute of Hungary, Budapest

and as well as Barczikayné Szeiler et al. (2009) and Pentelényi and Síkhegyi (2012) they wrote about the identity of the Fallon's map with the base map used for Haidinger's geognostic map (1845).

We have to mention that the Fallon's map (Fallon 1822) is the reduced map of the First Military Survey (1763-1787) on a scale of 1:864,400, which contains 9 sheets (Jankó 2007, p. 51). The Haidinger's map couldn't have been based on the Second Military Survey because its reduced map, the Scheda's map (1856) was compiled later and it has a different scale, namely 1:576,000 (Jankó 2007, pp. 82-83). Thus our opinion is that Fallon's map is the base map used for the geognostic map by Haidinger (1845).

On the map, Haidinger distinguished 22 kinds of rocks and stratigraphic units (several terms being in use even today) using 20 different colors and alphabetical symbols (Brezsnyánszky 1996; Brezsnyánszky and Síkhegyi 2007). The legend is predominantly petrographic, the geochronological names being subordinate, although the succession of the geological features can easily be recognized (Galambos 2004).

\subsection{The geological map of Transylvania by Hauer et al. (1863)}

In the mid-nineteenth century, Transylvania was classified as an extremely important province for mapping (Brezsnyánszky 1996). Thus, in addition to the systematic mapping of the Empire, local mappings were carried out on the territory of Transylvania, these being performed predominantly by Bielz (1854a, b), Peters (1858), Hauer (1861), Hauer et al. (1863) (Brezsnyánszky 1996; Barczikayné Szeiler et al. 2009). The geological map of Transylvania (Fig. 2) compiled by Franz Ritter von Hauer, Dionis Štur and Guido Stache 
was published in 1863 on a scale of 1:288,000, using the map sheets of the Second Military Survey as topographic basis (Brezsnyánszky 1996; Barczikayné Szeiler et al. 2009). At the same time it is important to mention that Hauer and Stache published, also in 1863, one of the first monographs on the geology of Transylvania (Gaudenyi and Jovanovic 2011) entitled: Geologie Siebenbürgens (Hauer and Stache 1863).

We can state precisely that the topographic base map is identical with the general map of Transylvania (on a scale of 1:288,000) consisting of 4 sheets (MGI 1863), which is a reduced map of the Second Military Survey.

The legend of the map by Hauer et al. (1863) distinguishes (based on the geochronological classification system) 43 lithological and stratigraphical units using different colours, lines and surface signs. This map exceeds considerably the level of the previously compiled ones (showing Transylvania), as what concerns its conception and up-to-date features (Brezsnyánszky 1996).

\subsection{The geological map of the Habsburg Empire by Hauer, sheet VIII (Hauer 1867-1871)}

Based on several geological maps and research documents resulting from the detailed as well as the overall mapping done during the previous period of over a decade by the Imperial Geological Institute (Vienna), Franz Ritter von Hauer compiled a new overall geological map

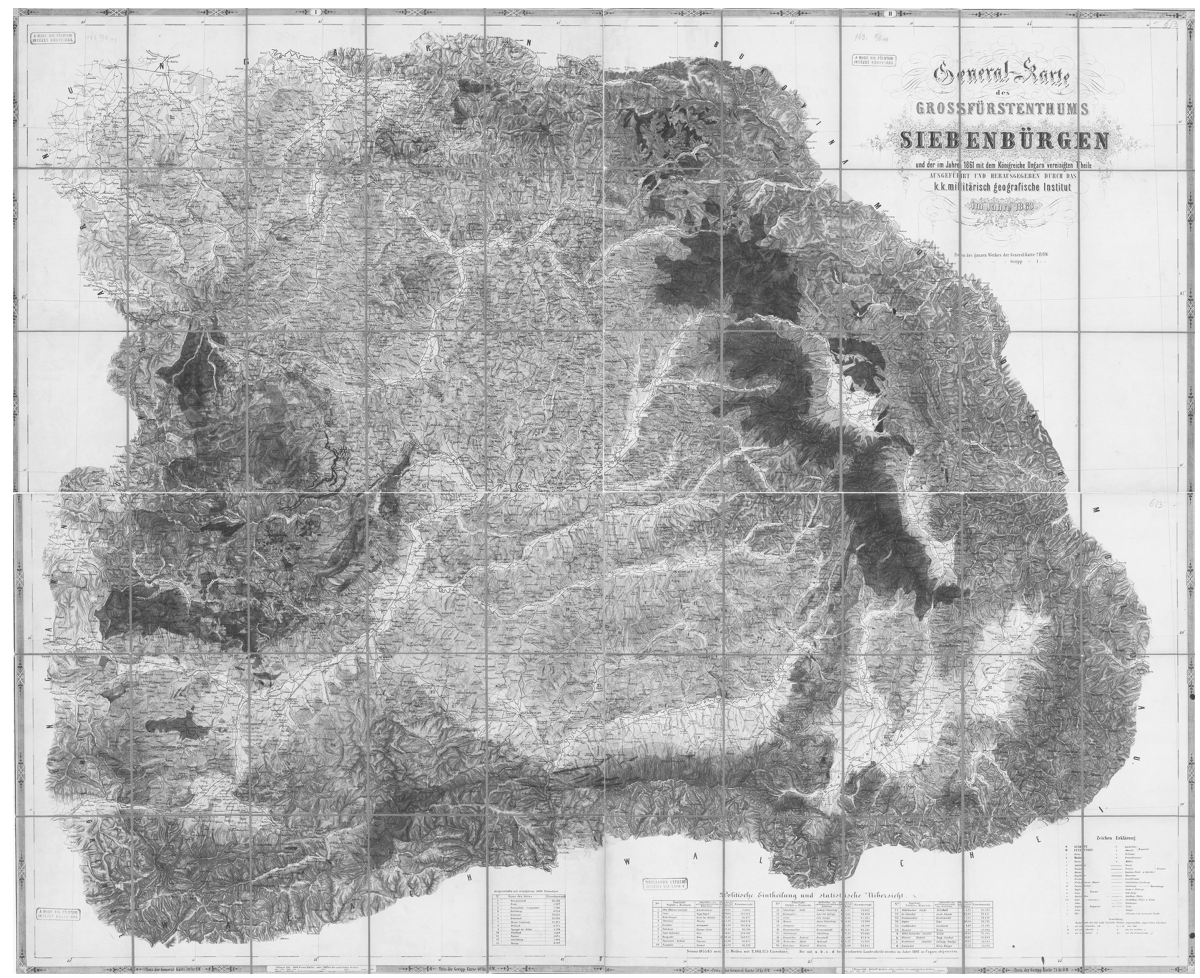

Fig. 2 The geological map of Transylvania (General-Karte der Grossfürstenthums Siebenbürgen und der im Jahre 1861 mit dem Königreiche Ungarn vereinigten Theile), 1:288,000 (Hauer et al. 1863) Collection of the Library of the Geological and Geophysical Institute of Hungary, Budapest 
showing the entire Austro-Hungarian Monarchy (Fig. 3) at a scale of 1:576,000. The map comprises 12 sheets which were published in Vienna between the years 1867-1871 (Brezsnyánszky 1996; Barczikayné Szeiler et al. 2009; Maigut 2010, p. 13). At the same time, Hauer published several explanatory notes for the different sheets of his map, among them one that is related to the sheet showing Transylvania (Hauer 1873).

According to Brezsnyánszky (1996) and Barczikayné Szeiler et al. (2009), the topographic basis of the map was deduced from the sheet series of the Second Military Survey. Because its scale is the same as the scale of the map by Scheda (1856), it would be reasonable to believe that its topographic base map was Scheda's map, but Pentelényi and Síkhegyi (2012) mentioned that the two maps are different, and Hauer's base map is an earlier one.

Analyzing these two scanned maps we reached the conclusion that the geological map by Hauer (1867-1871) could have used Sheda's map as its topographic basis-despite the fact that the drawings of the two maps are truly different-because the hydrography is the same, the routes and settlements on Hauer's map could have been generalized from the topographic map, though the lettering is different. The projections of the two maps are

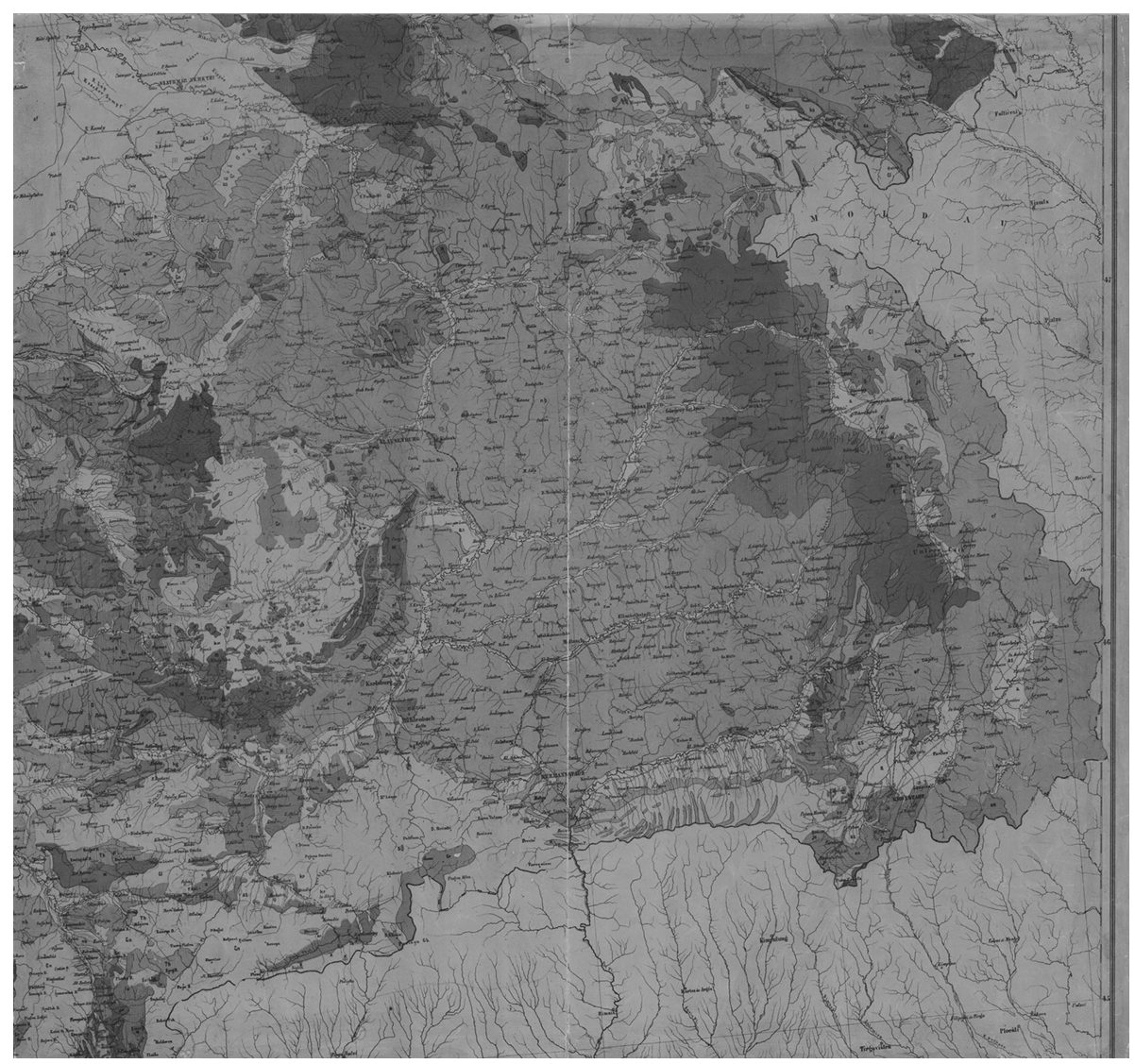

Fig. 3 Sheet VIIIth (showing Transylvania) of the geological map of the Austro-Hungarian Empire (Geologische Übersichts-Karte der Österreichisch-Ungarischen Monarchie), 1:576,000 (Hauer 1867-1871) Collection of the Library of the Geological and Geophysical Institute of Hungary, Budapest 
almost the same; we cannot decide if the differences are the results of redrawing, different sectioning and different scanning, or these two maps are different indeed.

The legend of the geological map by Hauer is much more detailed than any other map's ever before, showing 102 kinds of geological formations and it is based on the stratigraphic time scale classification system (Brezsnyánszky 1996; Brezsnyánszky and Síkhegyi 2007).

\subsection{The geological map of the Seklerland by Herbich (1878a)}

The geological map of the Seklerland (Székelyföld, Ţinutul Secuiesc) by Ferencz Herbich (Fig. 4) was published in 1878 by the Royal Hungarian Geological Institute (Budapest), as

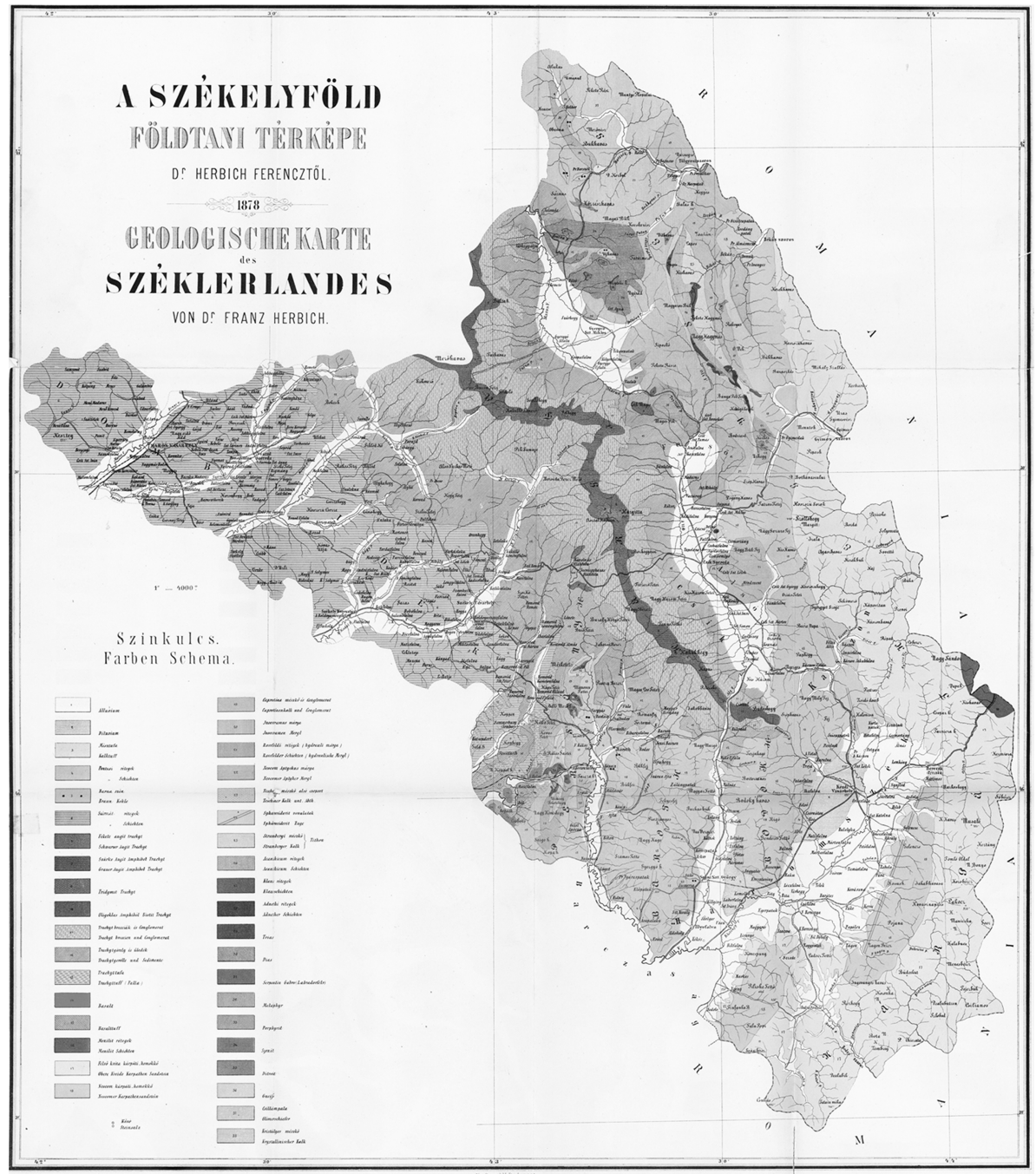

Fig. 4 The geological map of Seklerland (A Székelyföld földtani térképe), 1:288,000 (Herbich 1878a) Collection of the Library of the Geological and Geophysical Institute of Hungary, Budapest 
an appendix to the author's monographic work (Herbich 1878b). The map has a scale of $1: 288,000$ and according to Galambos and Unger (2009) its topographic basis was derived from the map series based on the Second Military Survey.

Based on our observations, we can state that the projection is almost the same as the projection of the map by Hauer et al. (1863), in other words almost the same as the projection of the MGI (1863); only a rotation was used to make longitude $43^{\circ}$ East from Ferro to be the central meridian instead of $42^{\circ}$. We use once again the adverb 'almost' because there are little differences which could have been caused by redrawing and scanning etc.

The geological formations are shown by colors, surface signs and alphabetical symbols, but the usage of the colors doesn't follow any standards, it only fits the choice of the author (Galambos and Unger 2009).

\section{Methodology}

To georeference a raster image, one first needs to define the coordinate system (and its projection parameters), then to establish and locate some control points (GCPs-Ground Control Points) on the map and to input the known coordinates of these control points. The georeference of the analyzed geologic maps has been performed using Global Mapper v13.00.

For a correct georeferencing of a map it is important to know its geodetic basis, especially as what regards the projection, geodetic datum and prime meridian used. The determination of the projection and its parameters of geological maps is based on the assumption that geological maps rarely have an independent geodetic or topographic survey, but they are compiled using as basis a pre-designed topographic or regional map, peculiar to a period, on which the geological data are drawn (Galambos 2010a, b).

After defining the maps projection with the parameters, we have to define control points on the map and determine their coordinates. In this process we applied different methods, depending on the possibilities that each map provided for us. If the coordinate grids are drawn, we can define the control points at their crossings. If they're not, but geographic coordinates are indicated, the georeference can be performed using the coordinates of the four corner points of the map. But if neither the coordinate grids nor the geographic coordinates are indicated, objects with well-known coordinates can be established as control points (in our case coordinates of settlements obtained from the Google Earth).

When the crossings of the coordinate grid lines or the coordinates of the corners of the map are used as control points, the prime meridian is of major importance. The coordinatevalues must be calculated taking this into consideration. All the analyzed geological maps used the prime meridian of Ferro, which was rather an artificial meridian of origin and was widely used prior to the end of the nineteenth century (prior to the Washington Conference on Prime Meridian and Universal Day, 1884, where using the prime meridian of Greenwich all around the world was suggested) (Timár 2007).

At the same time it is extremely important to know that the geographic coordinates must be converted into projected ones using transformation formulas (Timár and Molnár 2013, p. 44). This conversion was made automatically by the software we used (Global Mapper $\mathrm{v} 13.00)$ in the process of georeferencing. The definition of the control points was made in Global Mapper v13.00 with automatic rectification method. 
The last step of the georeferencing is the rectification. During this process the software calculates the coordinates of all pixels of the raster image. If we have estimated correctly the projection and its parameters, the resampled map will be a rectangle with horizontal and vertical margins (Timár and Molnár 2013, p. 45). The maps we studied were resampled by bilinear interpolation method.

The base map of the Haidinger's geognostic map (1845) is supposed to be the map by Fallon (1822), which is a reduced map of the First Military Survey. According to Jankó (Jankó 2007, pp. 22-24, 51), we don't have information about the geodetic datum and projection of the maps of the First Military Survey, despite the fact that the Fallon's map (1822) is the only map on which the geographic coordinates are marked on frame.

We analysed the projection of Fallon's map (1822): the meridians are straight lines, the angular distance between them is reduced; therefore the map has a conic projection, where the cone constant (n) measured by us is cca. 0.77 . So we calculated the standard parallel (in tangent case) as $50^{\circ}$ North. We measured the central meridian at $35^{\circ}$ longitude East from Ferro. The distances between the parallels are increasing, moving away from the estimated standard parallel, which reinforce our premise that it could be a conformal projection, due to its topographic use. Hence we consider that the projection of the map by Fallon (1822) could be substituted with a tangent conformal conic projection with the above parameters.

Based on the fact that the geodetic and topographic basis of the map by Haidinger (1845) is uncertain (the projection and the parameters of the map by Fallon (1822) being only presumed and estimated, but not unambiguous), in this case the georeference was performed using coordinates of 45 settlements as control points.

The topographic basis of the geological map by Hauer et al. (1863) is identical with the map by MGI (1863). The geodetic datum of the Second Military Survey and the projection used for the reduced map are known.

The area covered by this survey involves 15 states today, thus it was necessary to create 8 different triangulation networks with different reference points (Jankó 2001; Timár and Molnár 2003; Timár et al. 2006, 2008, 2011). In Transylvania, the triangulation network was developed on the hybrid ellipsoid of Zach-Oriani (semi-major axis: $6376130 \mathrm{~m}$; semiminor axis: 6355562.258 m; inverse flattening: 1/310) (Varga 2002; Timár 2004; Timár and Molnár 2003). The origin was set to the observatory that functioned in that time on the hill of Dealul Ocna Sibiului, North-West of Sibiu (Ocna Sibiului datum) (Varga 2002). The geodetic datum of the maps compiled in the nineteenth century are not introduced into GIS software, thus we needed to enter them manually. The Molodensky-type transformation parameters between the Ocna Sibiului datum and WGS84 were determined by Timár and his colleagues (Timár et al. 2004, 2007): dX $=+1734 \mathrm{~m}, \mathrm{dY}=+376 \mathrm{~m}$, $\mathrm{dZ}=+595 \mathrm{~m}$, while the point of origin in respect to the surface of reference was given by Varga (2002): $\varphi=45^{\circ} 50^{\prime} 25.13^{\prime \prime}$ (the latitude of the origin) and $\lambda=24^{\circ} 6^{\prime} 46.69^{\prime \prime}$ (the longitude of the origin, East from Greenwich). The above values in the case of longitude were initially given for the meridian of origin Ferro. The Ferro-Greenwich difference has been considered by us being of 17³9'46.02" (Timár and Molnár 2003).

Although the Cassini-Soldner projection was used for the map sheets of the Second Military Survey at a scale of 1:28,800, the MGI (1863) reduced map with the scale of 1:288,000 was compiled using the Bonne projection (Jankó 2007, pp. 80-82), as reduced maps were in general. The exact parameters of the pseudoconical equal-area Bonneprojection are not known. It is obvious that the longitude of central meridian is $42^{\circ}$ East from Ferro; in turn as standard latitude we have determined the central one, namely the $46.5^{\circ}$ parallel North. We defined our control points in all crossings of the grid lines. 
The base map of Hauer's geological map (1867-1871) is uncertain. It could be the map by Scheda (1856) or another one. The geodetic datum and the map projection of the Scheda's map is as above (Zach-Oriani and Bonne), but the parameters of the projection are different. Since we obtained the map sheets without unambiguous border information, we couldn't determine the exact parameters (the central meridian could be at $15-16^{\circ}$ East from Ferro and the standard latitude could be the $46-47^{\circ}$ parallel North). Hence we used about 40-50 settlements as control points.

Presumably the projection of the map by Herbich (1878a) is the same as the projection used for the map by Hauer et al. (1863); therefore we used, also in this case, the geodetic datum (Zach-Oriani) and projection (Bonne) as above. Our control points were all the crossings of the grid lines.

\section{Results and discussions}

The above described georeferencing methods have been applied on the studied maps with the aim of rectifying them in their initial projection (and geodetic datum). Afterwards, the maps have been converted into Stereo70 projection using the classical method of reprojection in Global Mapper v13.00, which enables us to incorporate them into a modern GIS database and to combine them with other GIS datasets [e.g. SRTM elevation dataset (Werner 2001; Timár et al. 2003)]. The precision and accuracy of the determination of the projections and their parameters have been verified through several methods. On the one hand the aspect of the rectified images has been analyzed, while on the other hand the georeferenced maps have been exported in $\mathrm{KML} / \mathrm{KMZ}$ format and the resulting errors have been analyzed on the surface of Google Earth. Finally, the maps have been analyzed with the MapAnalyst software.

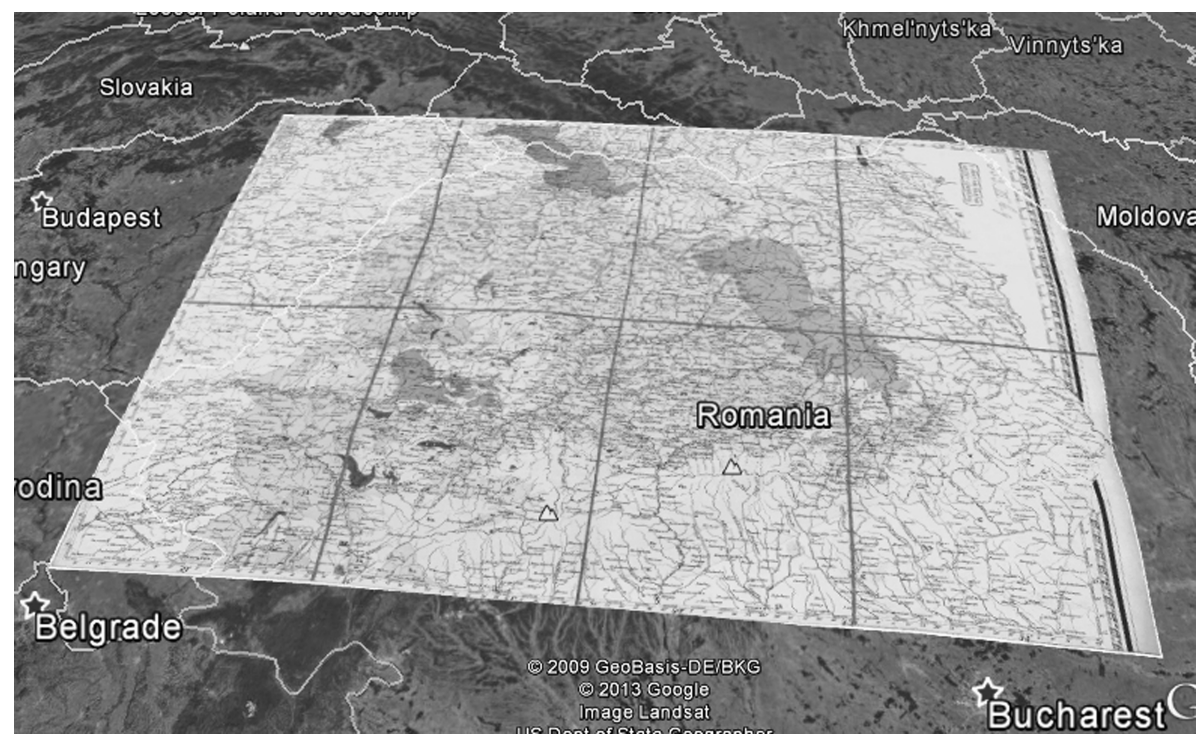

Fig. 5 The VIth sheet of the geognostic map by Haidinger (1845) on the surface of Google Earth 
Although it has got marked geographic coordinates on frame, in the case of the VIth sheet of the map of the Habsburg Empire by Haidinger (1845), the rectification has been performed using geographic coordinates of 45 settlements obtained from Google Earth because we didn't have precise geodetic and projection information and because this is a map sectioned and mounted on a cloth backing. The resulting errors have been analyzed on the map exported to the surface of Google Earth (Fig. 5), the horizontal accuracy of the fit being usually of $0-2.5 \mathrm{~km}$, acceptable for the small scale $(1: 864,000)$ of the map and taking into account the printing technique.

On the map of Transylvania by Hauer et al. (1863) all the crossing points of the grid lines were used as control points. The accuracy was analyzed using MapAnalyst software.

As old map we imported the georeferenced Hauer et al. (1863) image, which was first reprojected into Mercator projection. As new map we used the Open Street Map (in Mercator projection). We linked 15 towns as control points. After computing according to Helmert-transformation, the results of transformation are the followings: the error in rotation is only $0.032^{\circ}$, the standard deviation is $587 \mathrm{~m}$ (at the scale of the map: $2.03 \mathrm{~mm}$ !), the root mean square position error is $830 \mathrm{~m}$, while the maximum difference is $1545 \mathrm{~m}$. The distribution of the displacement errors is not systematic but accidental; therefore it is caused by the surveying errors and not by the georeferencing problems (Fig. 6).

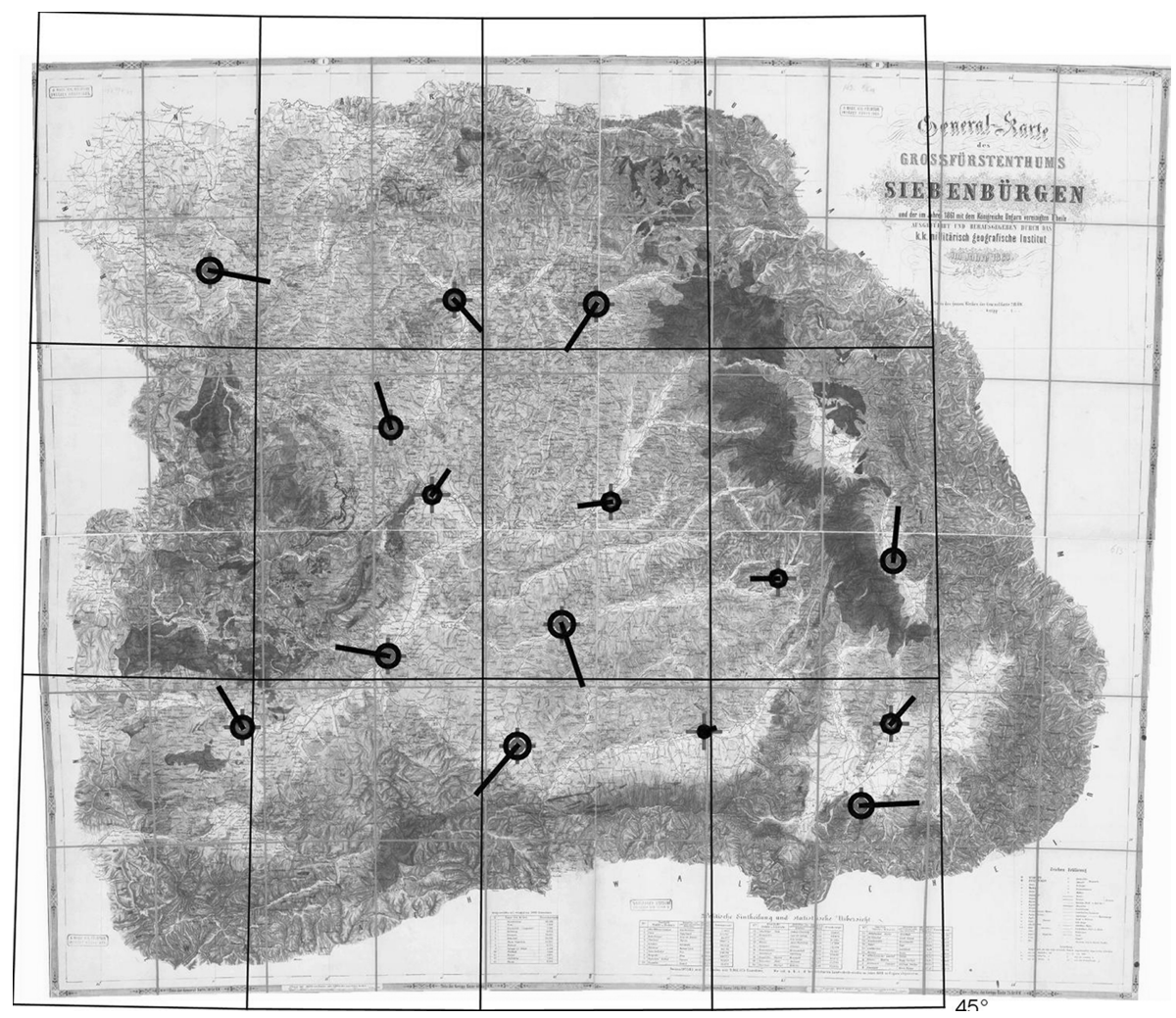

Fig. 6 Analysis of the map by Hauer et al. (1863) in MapAnalyst. The scale factor of the displacement vectors and circles is 20 
The VIIIth sheet (showing Transylvania) of the Habsburg Empire's map by Hauer (1867-1871) has been rectified defining 44 control points with known geographic coordinates and the resulting errors obtained from the map exported to the surface of Google Earth (Fig. 7) were generally of $1-1.5 \mathrm{~km}$, rarely reaching values of $2.5-3.5 \mathrm{~km}$.

The geological map of Seklerland by Herbich (1878a) has been studied and georeferenced by others too (Galambos and Unger 2009). In the process of georeferencing we used all the crossing points of the grid lines as control points. The accuracy was analyzed using MapAnalyst software. As old map we have the georeferenced Herbich (1878a) image, reprojected first into Mercator projection, while as new map we used the Open Street Map (in Mercator projection). We linked 12 towns as control points. After computing according to Helmert-transformation, we obtained the following transformation results: the error in rotation is only $0.194^{\circ}$, the standard deviation is $309 \mathrm{~m}$ (at the scale of the map: $1.07 \mathrm{~mm}$ !), the root mean square position error is $437 \mathrm{~m}$, the maximum difference is $856 \mathrm{~m}$. The distribution of the displacement errors is not systematic in this case either, it is accidental; in consequence it is due to the surveying errors and not to the georeferencing problems (Fig. 8).

In general we can note that the errors are mostly due to the small scale of the maps, to the surveying and printing techniques (the errors caused by the cloth-backedness and foldings being under $1 \%$ ), as well as to the post processing methods (e.g. scanning) and to the manual introducing of the control points. But they are also caused by the fact that geologic maps (thematic maps in general) don't have independent geodetic basis, but they use existing topographic or regional maps on which geologic data are drawn, so they can be considered "second hand" maps.

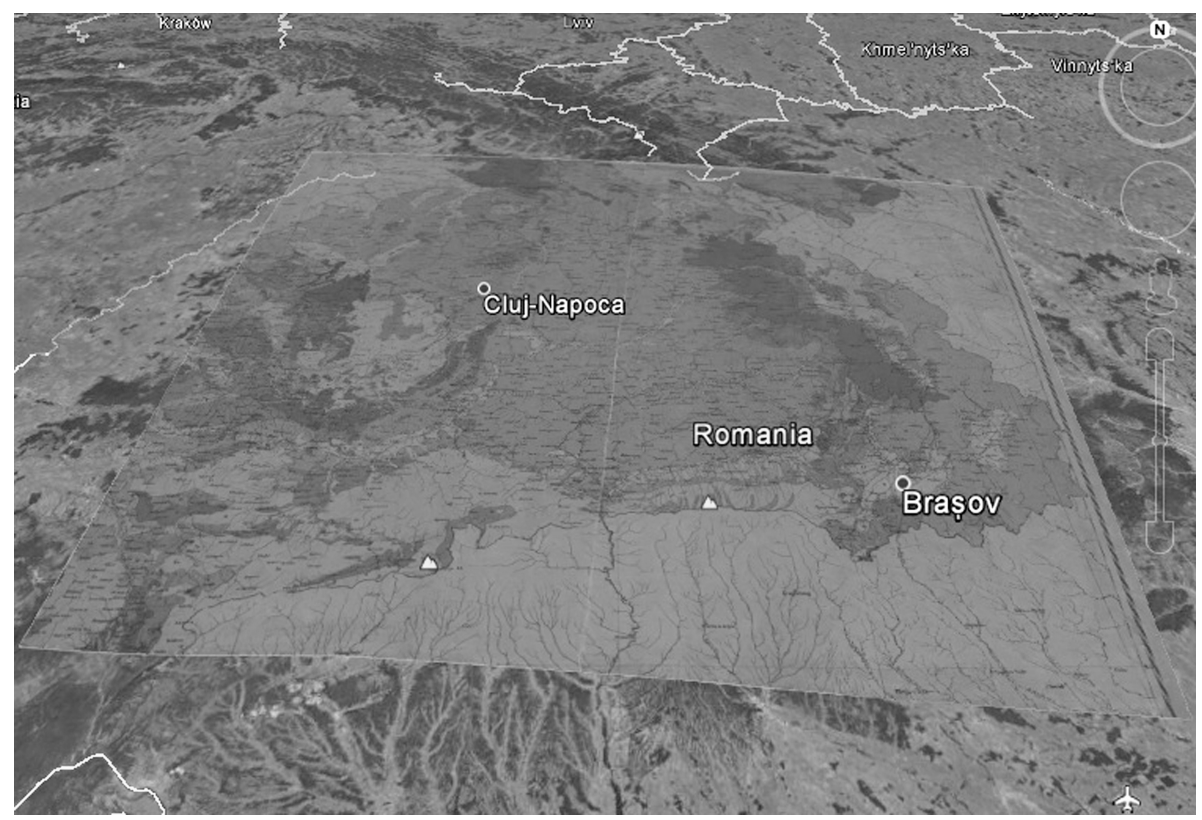

Fig. 7 The VIIIth sheet of the geological map by Hauer (1867-1871) on the surface of Google Earth 


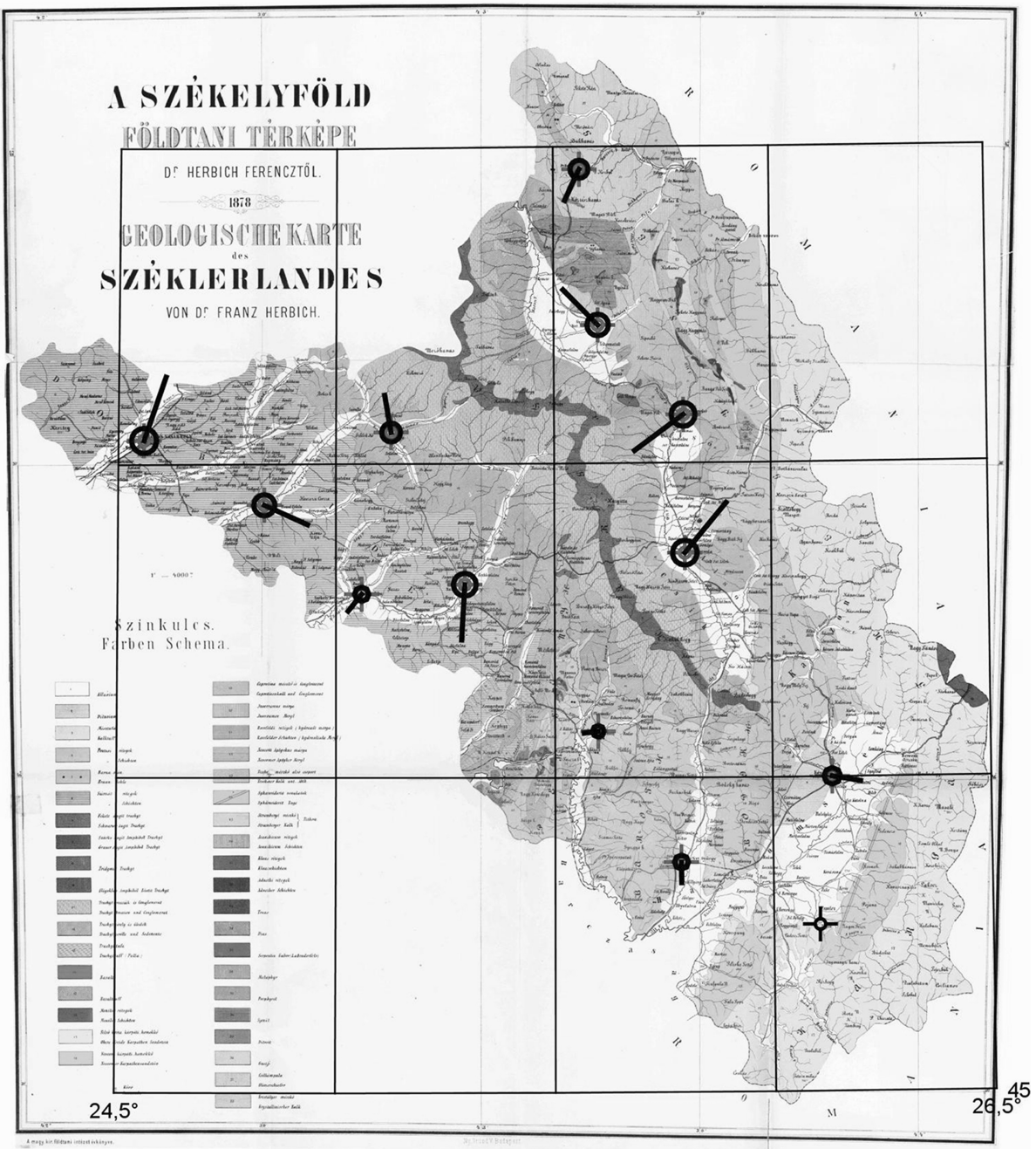

Fig. 8 Analysis of the geological map by Herbich (1878a) in MapAnalyst. The scale factor of the displacement vectors and circles is 20

\section{Conclusions}

The results of georeferencing (map projections, geodetic datums, parameters of the center of the projections, average horizontal errors) — as the main message of this study — together with some other characteristics of the maps have been summarized in Table 1.

The target of this paper is a research area (historical cartography) that represents on international level a new approach to the study of the past and its comparison with the present based on the scientific investigation of the old maps using GIS techniques. At the same time the theme of this paper can be considered as part of the European and worldwide trend of revaluation of the patrimony of thematic cartography in a geoinformatic or 
Table 1 Cartographic characteristics of the maps

\begin{tabular}{|c|c|c|c|c|}
\hline $\begin{array}{l}\text { Title, author and year of } \\
\text { publication of the map }\end{array}$ & Scale & $\begin{array}{l}\text { Prime } \\
\text { meridian }\end{array}$ & $\begin{array}{l}\text { Projection, geodetic datum and } \\
\text { parameters }\end{array}$ & $\begin{array}{l}\text { Average } \\
\text { horizontal } \\
\text { errors }\end{array}$ \\
\hline $\begin{array}{l}\text { The geognostic map of the } \\
\text { Habsburg Empire } \\
\text { (Haidinger 1845) }\end{array}$ & $1: 864,000$ & Ferro & $\begin{array}{l}\text { Presumably the same as the map by } \\
\text { Fallon (1822) }\end{array}$ & $0-2.5 \mathrm{~km}$ \\
\hline $\begin{array}{l}\text { The geological map of } \\
\text { Transylvania (Hauer et al. } \\
\text { 1863) }\end{array}$ & $1: 288,000$ & Ferro & $\begin{array}{l}\text { Zach-Oriani hybrid ellipsoid } \\
\text { Molodensky-type transformation } \\
\text { parameters: } \mathrm{dX}=+1734 \mathrm{~m}, \\
\mathrm{dY}=+376 \mathrm{~m}, \mathrm{dZ}=+595 \mathrm{~m} \\
\text { Bonne projection }\left(\mathrm{E} 42^{\circ}, \mathrm{N} 46.5^{\circ}\right)\end{array}$ & $587 \mathrm{~m}$ \\
\hline $\begin{array}{l}\text { The geological map of the } \\
\text { Austro-Hungarian Empire } \\
\text { (Hauer 1867-1871) }\end{array}$ & $1: 576,000$ & Ferro & $\begin{array}{l}\text { Presumably the same as the map by } \\
\text { Scheda (1856) }\end{array}$ & $1-1.5 \mathrm{~km}$ \\
\hline $\begin{array}{l}\text { The geological map of } \\
\text { Seklerland (Herbich 1878a) }\end{array}$ & $1: 288,000$ & Ferro & $\begin{array}{l}\text { Zach-Oriani hybrid ellipsoid } \\
\text { Molodensky-type transformation } \\
\text { parameters: } \mathrm{dX}=+1734 \mathrm{~m}, \\
\mathrm{dY}=+376 \mathrm{~m}, \mathrm{dZ}=+595 \mathrm{~m} \\
\text { Bonne projection }\left(\mathrm{E} 43^{\circ}, \mathrm{N} 46.5^{\circ}\right)\end{array}$ & $309 \mathrm{~m}$ \\
\hline
\end{tabular}

geomatic approach. Although similar works have been published concerning the old geologic maps of Hungary (Galambos 2009a, b, 2010a; Galambos and Unger 2009), a GIS database that integrates old geologic maps showing Transylvania hasn't been realized until now. Georeferencig these geologic maps enables us to incorporate the geological data and knowledge from the second half of the nineteenth century with the present datasets into a unified GIS system. Thus the geologic content of these can become comparable both in quantitative and qualitative ways. It is of major interest to combine these georeferenced maps with SRTM datasets (Werner 2001; Timár et al. 2003), from which a three dimensional representation of the geologic formations results.

The present research can be considered useful not only in the perspective of historical cartography, but also due to the fact that geologic data are extremely important from economic, as well as strategic point of view.

Acknowledgments The maps of this study are properties of the Library of the Geological and Geophysical Institute of Hungary. We would like to thank the staff of the library for their accessibility.

\section{References}

Barczikayné Szeiler R, Gyalog L, Hegyiné Rusznyák É, Viktor Zs, Orosz L, Pentelényi A, Síkhegyi F (2009) A földtani térképezés 140 éve-Térképválogatás a XVIII. századtól napjainkig. MÁFI kiadásDVD, Budapest

Bielz EA (1854a) Karte der geognostischen Verhältnisse des Grossfürstenthums Siebenbürgen. Map, scale: $\mathrm{M}=1: 864,000$. Manuscript. Hermannstadt (Sibiu)

Bielz EA (1854b) Karte der Verbreitung der Salzquellen und des Steinsalzes in Siebenbürgen mit Rücksicht auf die geognostischen Verhältnisse dieses Landes. Map, scale: $M=1: 864,000$. Manuscript. Hermannstadt (Sibiu)

Brezsnyánszky K (1996) Austro-Hungarian geological mapping before 1869. Advances In: AustrianHungarian Joint Geological Research, Budapest, pp 25-32 
Brezsnyánszky K (2001) Földtani térképezés: Terepi felvételezés-Térképi összegzés. Jegyzet a NyugatMagyarországi Egyetem Kitaibel Pál Környezettudományi Doktori Iskola hallgatói számára, Budapest

Brezsnyánszky K (2007) Geological maps. Nova Acta Leopoldina NF 94(349):71-79

Brezsnyánszky K, Síkhegyi F (2007) Das Ungarische Geologische Institut, eine herausragende Werkstatt der thematischen Kartographie. Nova Acta Leopoldina NF 94(349):47-69

Fallon LA (1822) Das Oestereichische-Kaiserthum mit betrachtlichen Theilen der angrenzenden Staaten. Map, scale: $\mathrm{M}=1: 864,000$. Wien

Galambos Cs (2004) Földtani térképek felületi jelei. Geodézia és Kartográfia 55(7):16-21

Galambos Cs (2009a) Developement of color signs and projections of the Hungarian archive geological maps. Acta Geod Geoph Hung 44(1):131-140. doi:10.1556/Ageod.44.2009.1.13

Galambos Cs (2009b) History of the Hungarian geological maps-an overview from the $18^{\text {th }}$ century to nowadays. In: Gartner G, Ortag F (eds) Proceedings of the first ICA symposium for central and Eastern Europe 2009. Vienna University of Technology, Vienna, pp 713-724

Galambos Cs (2010a) Projection analyzis and geo-reference of the old Hungarian geological maps. In: Gartner G, Livieratos E (eds) Proceedings of the 5th international workshop on digital approaches in cartographic heritage. Vienna University of Technology, Vienna, pp 183-188

Galambos Cs (2010b) Topographic basis and prime meridians used in historical Hungarian geological maps. Geophysical Research Abstract 12 EGU2010-3851

Galambos Cs, Unger Z (2009) Geological maps showing Transylvania from around 1900. Geogr Tech $1: 31-39$

Gaudenyi T, Jovanovic Mladjen (2011) Franz Ritter von Hauer's work and one of the first loess map of Central Europe. Quatern Int 234:4-9. doi:10.1016/j.quaint.2010.04.008

Haidinger W (1845) Geognostische Uibersichts-Karte der Oesterreichischen Monarchie. Map, scale: M $=1: 864,000$. K. K. Militärisch-Geographischen Institute, Wien

Hauer FR (1861) Geologische Übersichts-Karte von Siebenbürgen. Map, scale: M=1:576,000. Hermannstadt (Sibiu)

Hauer FR (1867-1871): Geologische Übersichts-Karte der Österreichisch—Ungarischen Monarchie nach den Aufnahmen der k. k. geologischen Reichsanstalt. Map, scale: M = 1:576,000. Wien

Hauer FR (1873) Geologische Uebersichtskarte der österreich-ungarischen Monarchie, Blatt VIII. Siebenbürgen. Jahrbuch der k. k. geologischen Reichsanstalt, 23(1):71-175

Hauer FR, Stache G (1863) Geologie Siebenbürgens. Wilhelm Braumüller K. K. Hofbuchhändler, Wien

Hauer FR, Štur D, Stache G (1863) General-Karte des Grossfürstenthums Siebenbürgen und der im Jahre 1861 mit dem Königreiche Ungarn vereinigten Theile. Map, scale: M = 1:288 000. Wien

Herbich F (1878a) A Székelyföld Földtani térképe. Map, scale: M = 1:288,000. In: Herbrich F (1878) A Székelyföld földtani és őslénytani leírása. Magyar Királyi Földtani Intézet Évkönyve V/2, Budapest

Herbich F (1878b) A Székelyföld földtani és őslénytani leírása. Magyar Királyi Földtani Intézet Évkönyve $\mathrm{V} / 2$, Budapest

Jankó A (2001) A második katonai felmérés. Hadtörténeti Közlemények, 114:103-129. http://epa.oszk.hu/ 00000/00018/00016/04janko.htm. Accessed 24 November 2014

Jankó A (2007) Magyarország katonai felmérései 1763-1950. Argumentum, Budapest

Maigut V (2010) A földtani térképszerkesztés geoinformatikai problémáinak megoldási lehetőségei. Doktori értekezés, Eötvös Loránd Tudományegyetem, Budapest

MGI (1863): General-Karte des Grossfürstenthums Siebenbürgen. Map, scale: 1:288,000. Militärgeographisches Institut, Wien

Pentelényi A, Síkhegyi F (2012): Hazai földtani térképeink topográfiai alapjai. In: A MÁFI évi jelentése 2010. Budapest, pp 81-95

Peters KF (1858) Geognostische Uibersichts-Karte der Umgegend von Rézbánya im Gebiete der schwarzen und der weissen Körös im südöstlichen Ungarn. Map, scale: $M=1: 288,000$. Wien

Scheda J R (1856) General-karte des Oesterreichischen Kaiserstaates. Map, scale: M = 1:576,000. Militärgeographisches Institut, Wien

Timár G (2004) GIS integration of the second military survey sections-a solution valid on the territory of Slovakia and Hungary. Kartografické listy 12:119-126

Timár G (2007) A ferrói kezdőmeridián. Geodézia és Kartográfia 59(12):3-7

Timár G, Molnár G (2003) A második katonai femérés térképeinek közelítő vetületi és alapfelületi leírása a térinormatikai alkalmazások számára. Geodézia és Kartográfia 55(5):27-31

Timár G, Molnár G. (2013) Map grids and datums. Eötvös Lóránd University. http://elte.prompt.hu/sites/ default/files/tananyagok/gridsanddatums/book.pdf Accessed 12 Feb 2015

Timár G, Telbisz T, Székely B (2003) Ürtechnológia a digitalis domborzati modellezésben-SRTM-adatbázis. Geodézia és Kartográfia 55(12):11-15 
Timár G, Molnár G, Păunescu C, Pendrea F (2004) A második és harmadik katonai felmérés erdélyi szelvényeinek vetületi- és dátumparaméterei. Geodézia és Kartográfia 56(5):12-16

Timár G, Molnár G, Székely B, Biszak S, Varga J, Jankó A (2006) Digitized maps of the Habsburg Empire-the map sheets of the Second Military Survey and their georeferenced version. Arcanum, Budapest

Timár G, Molnár G, Imecs Z, Păunescu C (2007) Datum and projection parameters for the Transylvanian sheets of the 2nd and 3rd military surveys. Geographia Technica 1:83-88

Timár G, Molnár G, Székely B, Biszak S, Varga J, Jankó A (2008) Planurile celei de-a doua ridicări topografice şi varianta lor georeferenţiată. Revista de Geodezie, Cartografie şi cadastru 17(1-2):3-15

Timár G, Biszak S, Balázs Sz, Molnár G (2011) Digitized Maps of the Habsburg Military Surveys Overview of the Project of ARCANUM Ltd. (Hungary). In: Jobst M (ed) Preservation in digital cartography. Lecture Notes in: Geoinformation and Cartography, pp 273-283. doi: 10.1007/978-3-64212733-5_14

Varga J (2002) A vetületnélküli rendszerektől az UTM-ig. Kézirat, BME, Budapest http://www.agt.bme.hu/ staff_h/varga/Osszes/Dok3uj.htm. Accessed 24 Nov 2014

Werner $\bar{M}$ (2001) Shuttle radar topography mission (SRTM), mission overview. J Commun (Freq) 55:75-79. doi:10.1515/FREQ.2001.55.3-4.75 